\title{
MODERN PR TECHNOLOGIES AND INSTITUTIONS OF SOCIAL MEMORY: PRACTICE OF USE
}

\author{
${ }^{a}$ Tetiana Klynina, ${ }^{b}$ Oleksandr Markovets \\ ${ }^{a}$ National aviation university (Kyiv, Ukraine) \\ ORCID: http://orcid.org/0000-0002-0332-9855 \\ ${ }^{b}$ Lviv Polytechnic National University (Lviv, Ukraine) \\ ORCID: http://orcid.org/0000-0001-8737-5929
}

\section{INTRODUCTION}

Among today's social institutions that perform the functions of preserving national memory, archives, libraries and museums have a special role to play. They, as social multifunctional special institutions, collect, preserve, research and make available to the public historical and cultural sources, historical artifacts that witness the development of society in its many dimensions. Those sources that contain archives, libraries and museums, in themselves are carriers of social, collective and cultural memory and accumulate the historical experience of the nation, serve as a kind of historical documentary repository of the state in the implementation of its functions, as well as active communication a means of preserving and transmitting cultural values from generation to generation, a mediator between the past, present and future. In essence, these institutions of social memory actualize the past, preserve historical sources for the reproduction of culture, and are indicators of sociocultural change [2]. Recently, there has been a growing interest in the institutions of social memory, which have long outgrown the socially established definition and perception of their essence. Today's institutions of social memory are intensively developing, undergoing not only quantitative but also qualitative changes, becoming platforms for communication between different social groups. The community of museums, archives and librarians is increasingly recognizing the idea of "integrated" institutions that go beyond the conservation, demonstration and translation of historical and cultural heritage and move to a broader social mission of cultural identification and integration into the environment. Today's integration into the communication environment is most effectively carried out using such technologies.

\section{ANALYSIS OF RECENT RESEARCH AND PUBLICATIONS}

The study of the functions of archives, libraries, museums as institutions of social memory is a topical issue in the foreign humanities. Such scientists as B. Delmas, R. Jimerson, D. Kahn, E. Ketelaar, R. Cox, T. Cook, B. Craig, W. Afiani, K. Gelman-Vinogradov, T. Khorkordin, and others. Ukrainian scholars also oppose the assessment of memory institutions as passive and diminish their role. They widely consider the social role of these institutions as aimed at actively influencing the development of society and reveal the possibilities of interdisciplinary integration of heritage (G. Boryak, L. Dubrovina, A. Kyridon, I. Matyash and others) [2]. However, the issue of using PR tools in the activities of social memory institutions has not been sufficiently analyzed in the works of both foreign and Ukrainian scientists. Although it is worth noting that some steps in this direction are still being taken. Such Ukrainian researchers as I. Tiurmenko, L. Khaletska, T. Klynina, Y. Kondrashevska, L. Bozhuk, etc. focus on the use of digital communications and Internet technologies in the activities of certain types of institutions of social memory, such as archives and children's libraries $[3 ; 4 ; 9 ; 10 ; 11 ; 12]$. However, to date there are no comprehensive studies on the use of a wide range of PR tools that exist today.Therefore, the purpose of the article is to present the maximum range of PR tools that 
are used or can be used by institutions of social memory.3. Presentation of the main material of the study

\subsection{PR technology as a tool for image building}

Today, the concept of image has become widely used in various fields of science and practice. Image has become an integral part of any organization that directs its actions to create a favorable image in a market economy to establish harmonious relations with the public.Image today is interpreted as "the most economical way to generate and recognize a complex social reality; as a result of information processing; as a collapsed text; as a communicative unit with which to work with the mass consciousness, as well as as a "visual image of an object that emotionally affects people." The emotionality of the image requires finding special means to support it, because emotions are bright, but short-lived [1].

\subsection{Network PR tools}

Today's processes of informatization and digitalization of all spheres of life have moved society into the network sphere. The field of PR is no exception. The same laws apply in the network as in the offline environment: there is also a need to create a "correct" image of your company in the eyes of the target audience; you also need to work with people's concepts and beliefs about the company, its products or services; you also need to react quickly to criticism and block the attacks of opponents. All these tasks went offline.

Features of the online environment also affect PR tools on the Internet. Due to the popularity of web technologies, PR on the Internet has an explosive effect, so you need to know what methods to use for proper positioning.

Interaction with the Internet audience can be organized in several ways:

$\checkmark$ Through social services and resources

$\checkmark$ Through authoritative online media;

$\checkmark$ Through the company's own website [8].

The most popular tools of network PR are:

- SMO is an adaptation to social networks. This item should become the first number in the list of tasks, because the audience of social networks is growing every day. Brand pages on Facebook, Instagram and other similar platforms are small or large media with their readership. SMO will help attract the user to the community of your brand. Therefore, on the main resource of the company we place links to network accounts (with beautiful avatars and a sufficient number of subscribers);

- SMM, i.e. social media marketing, is a continuation of the SMO strategy. Using SMM methods, future customers are attracted to the brand's pages on social networks, creating interesting and useful content, as well as launching interactive promotions, contests, etc [5].

- Blogging. Interesting content is the basis of all online PR methods. Many business owners think that site visitors never go to the "Our Articles" section. In fact, a blog can be an important part of a PR campaign strategy: potential customers search for information by driving key queries into a search engine. And the more of these keys will be in the blog articles, the more often customers will come to your site. The effectiveness of the method can be assessed by the number of views, likes, comments and bundles - these points will help to understand what else the client wants to know and create interesting articles for him. The tasks of running a corporate blog of the company are in many respects similar to the tasks of creating groups on social networks or creating company profiles on popular and authoritative thematic forums. Its own corporate blog, in terms of PR on the Internet, helps the company to become "closer to the people", because the blogosphere is a kind of "barometer" of the interests of the Internet audience: any important event immediately finds a response in blogs [7].

- Viral marketing. Experts often answer the question of what PR is, one capacious and as old as the world phrase - "sundress radio". "Viral" marketing is an idea that will appeal to and 
"infect" a huge audience. People themselves will spread such information on social networks. To create a viral campaign you need to: create positive content, focusing on the strengths of the topic or concept [2]. The information should be focused on the bright response of the audience. The message should be useful and practical.

- SERM - PR image on the network. Sometimes companies order false positive reviews about themselves and negative ones about competitors. "White" methods are much more effective, because it is better to place a block with real feedback about yourself - both positive and moderately negative - in Landings or mailing lists. After all, the presence of different reviews will serve as proof that the company does not catch the eye. The user understands that everyone makes mistakes, and "sweet" reviews will not believe [7].

- Own group on a social network - the company will be able to add images from its group (for example, photos of sold goods or successfully completed projects), publish news and notes about the life of the company, organize discussions of new products, organize contests, promotions, etc [8].

- Own website - another important online PR tool for a company. It can be a representative site or a corporate, online store or advertising promotional site. Each of the types of sites helps to implement a certain range of PR tasks facing the company. The company's own website for business is its "virtual office" and it can take over all the functions of representing the company's interests on the Internet. However, the best effect in gaining popularity and recognition among Internet users can be achieved only with an integrated approach, when the site, a group of accompanying social profiles and advertising campaigns on the Internet interact closely with each other, complement each other [6].

- Forum. The company's participation in a popular thematic forum, relevant to the profile of its activities, will allow the company from the position of an expert to give advice to other participants of such a forum, to answer their questions. Competent, polite and competent messages in this case form a lasting positive impression of the forum visitors, and, in fact, this is the main purpose of PR on the Internet [5].

- Publication of news and notes about the company, press releases in the leading online media - an important tool of PR on the Internet. The wider the coverage of popular online newspapers and magazines, the more attention will be drawn to the company and its products or services. At the same time, it is sometimes much easier to get to the pages of popular online publications than to the pages of ordinary newspapers or on TV and radio [8].

The more honest the PR tools in the network, the longer-lasting the effect will be, and honest methods of attracting customers will provide a huge audience of regular customers.
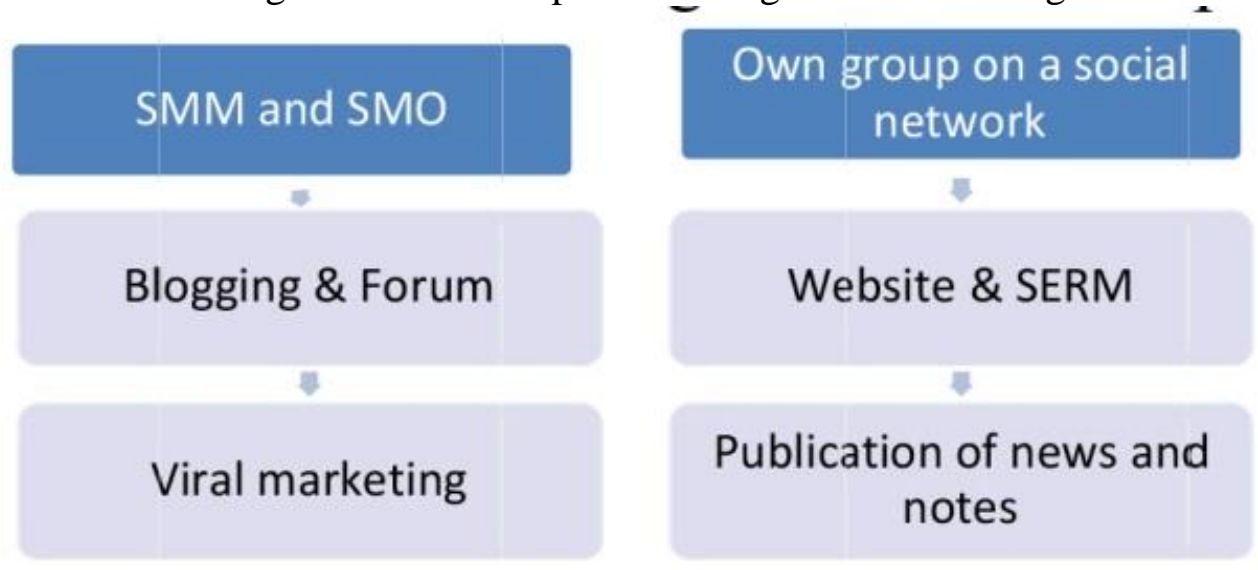

Fig. 1. The most popular tools of network PR

\subsection{Non-network PR technologies}

A press release is an official document with information for the media, which is sent or transmitted to journalists with a view to their interest in the topic, as well as for the publication 
of materials based on it. This is attention-grabbing material, a brief account of an event that has taken place. This PR technology is needed when there is a socially important reason for it (ie, the need not only for the organization but also for society).It has a certain structure: necessarily the title in which the informational reason is revealed, the date of sending; the exact name of the organization that produces it; information on where to clarify the information provided. A press release about the event to be held is submitted to the media no later than the day before the event, and about the event that took place - immediately after its completion [3].

A briefing is a short (up to half an hour) working event for media representatives, during which officials, representatives of state or commercial structures announce the news, state their attitude and indicate their position on a particular issue. Briefings are usually promptly organized in the event of emergencies (terrorist attacks, accidents, mass poisonings, traffic disruptions, communications, etc.) to explain as far as possible what happened, its causes, to prevent panic, possible mistakes, distortion of facts and exaggeration in the media. According to PR practitioners, "briefing is also the most convenient format for communicating sensational information designed to take the effect of surprise, because in this way the required information message veiled by sensational news will be uncritically perceived by the audience under the influence of strong emotions". The peculiarity of the briefing is that the reports of the speakers are one-sided, illustrated with specific facts. In most cases, the organizers of the briefing are limited to the message, without entering into a dialogue with the press. The working event for journalists is most often used in the practice of press services of the authorities back-briefing - a meeting of the first persons (statesmen, heads of departments) with representatives of mass media in the format "not for the press" on certain information occasions. The duration of the back-briefing also takes no more than half an hour, sometimes much less, and is dedicated to a specific event, news or issue [10].

Press conference - a meeting of representatives of government agencies, socio-political organizations, commercial structures with journalists in order to inform the public on current issues. The initiators of the press conference are mainly managers and specialists of various structures, organizations and companies, and sometimes media workers who, under pressure from various groups of the public, want to get detailed, qualified and official answers to questions. Press conferences are useful when it is necessary to inform the public about some important and extraordinary event in your life; demonstrate the achievements of the company or its new products; to present a new concept of development that arouses mass public interest; to resolve controversial issues that have long been discussed by the public; to establish personal contacts of the organization's management with media representatives. At a press conference, speakers should never delay their speeches: the speech should contain a minimum of information. The duration of the press conference is a maximum of 40 minutes, after which journalists should be able to work with individual participants [8].

The round table is a meeting of officials, specialists, experts, politicians, scientists and public figures and journalists to discuss in detail the current problem facing society and make some recommendations for its solution. It has two interpretations: as a free conference of various participants for direct discussion of specific problems (in particular, conflicts), less often as a closed society of elected officials who make important decisions on the sidelines. It is held in different situations and for different purposes: when a problem arises, to generate new ideas and discuss existing ones, to sum up, after an event. The type of group solution of certain issues, which is characterized by a certain order and sequence of statements of its participants, as well as equal rights and positions of all present. Most often, the round table plays an advocacy role. It is a simpler and softer form of discussion than discussion, debate, brainstorming, debate, or more complex forms such as public hearings, public expertise, problem seminars, and so on. In the modern sense, it is used as the name of one of the ways to organize a discussion of an issue and has the following features:

- the purpose of the discussion (generalization of ideas and opinions on the issue under discussion); 
- all participants act as proponents (express an opinion on the issue, not on the opinions of other participants);

- all participants in the discussion are equal, no one has the right to dictate their will and decisions [9].

Presentation - a specially organized communication with the audience for public transmission and presentation of something new or motivation for certain actions. It is a certain action, action (commonly used meaning): showing a new product, presenting new information to the general public (presentation of a new book, fashion collection, movie) as an advertising campaign for promotion. Provides live communication in the form of dialogue between the speaker and the audience using certain technical means. According to the "Training Dictionary of the Language of Public Relation", the presentation - PR-technology, which includes not only the demonstration of goods, companies or services for a specific target audience, but often theatrical or concert performance, dinner or buffet, auctions, sales, etc.In the activities of PR-units when using this technology we are talking about a specific "product". But in any case, the specifics of the presentation as a media event of the state PR-service is more businesslike, strict and serious approach: unlike commercial organizations, any steps of government agencies or branches of government are always iodine close attention of the media and society. In general, so there is no need for the entertainment part of the event, auctions or quizzes. The presentation will be more effective if you invite not only representatives of the general public, ie potential buyers, customers, but also representatives of the city administration, legislatures, famous people of the city. It is very good if correspondents of newspapers, radio and television will be invited to the opening ceremony [4].

Open days - a date set for free access to a particular institution, production, etc. for those wishing to study, get a job, get acquainted with the activities of the institution, organization, etc.This is a common form of self-presentation of the company in the framework of PR and promotion, which allows everyone to get acquainted with its activities, plans, ask questions to management on issues of interest. As a rule, excursions are conducted for the guests; where they tell about the history of creation, main directions of activity, social significance for the public, etc.

The exhibition is a public demonstration of achievements in the field of economics, science, technology, culture, art and other spheres of public life. Exhibition business is one of the most difficult activities in the system of marketing communications, primarily because it requires from the organizers careful preparation, specific knowledge regarding the specifics of exhibition activities. Some organizational issues of the complex of events are significantly different for permanent exhibitions and for exhibitions, short-term in operation, but both have the same goal through a series of events to increase interest in themselves, their products by the professional community. In this sense, the exhibition activity is very closely intertwined with the functions of public relations and corporate advertising.

Stages of exhibition activity:

- Pre-exhibition activities (interaction of organizers and organizers with exhibitors and partners, coordination, topics and programs of the event, selection of exhibits, marketing research, customer search, work with the media, etc.);

- The whole complex of exhibition service (organization of the exhibition and the whole complex of accompanying events);

- Post-exhibition activities (summarizing the work of the exhibition and implementing the results in practice, summarizing materials about customers, the best exhibits, know-how, scientific and technical products and goods, presentation and promotion).

The very form of the exhibition, as a means of public relations, allows integrated use for several days of exhibitions, sales promotion, personal contacts with visitors, as well as wide public coverage through the media. The system of public relations of the exhibition activity has different schemes depending on what the exhibitions are: multidisciplinary, branch, specialized.The exhibition can be organized by one company or the whole industry, last from several days to several months or even operate permanently (permanent exhibition). The exhibitions feature both goods and services for sale, as well as works of art, historical 
monuments (for example, the International Monetary Fund in Washington holds an exhibition of graphics on its premises; IBM has opened an online exhibition of Hermitage treasures around the world). It is important to remember that non-profit exhibitions work on the image.

Training is a form of group work that provides active participation and creative interaction of participants with each other and with the teacher. Training is designed to acquire or improve a particular skill through practice. Good training contains $10 \%$ of theoretical material, the rest - practice and automation of skills. Specific features of training:

- adherence to certain principles of group work;

- the presence of a more or less permanent group (preferably from 15 to 20 people who meet periodically or work continuously for two to five days);

- a certain spatial organization (most often - work in a comfortable isolated room, where participants spend most of the time sitting in a circle);

- use of active and interactive methods of work.

In the training session, preference is given not to the teacher, but to students whose personal experience is the basis for learning. It is not necessary to give lectures, it will be expedient if students (participants) share what they know at the moment, and find and / or assimilate the information which is not enough. The teacher in the training plays the role of facilitator (from the English. Facilitate - to help, facilitate, promote). It directs the activities and interaction of participants to study the topic and achieve the goal of the training.

Master class is a form of lesson in which the teacher shares the experience of his work through direct commentary and demonstration of the most effective methods, techniques, forms of pedagogical activity, planning their application by all participants. It is conducted by a specialist in a certain field of creative activity (music, fine arts, literature, directing, acting, design, crafts) for people who, as a rule, have already reached a sufficient level of professionalism in this field [9].

Sponsorship - a system of mutually beneficial contractual relations between the sponsor, which is a provider of funds, resources and services, and the recipient - the party receiving them, represented by individuals, groups, organizations in order to achieve certain marketing communication goals. Financing of the program, project, event both for the purpose of its support, and for advertising of own activity.Provides for direct or indirect withdrawal of profits or other benefits. The European Association of Sponsorship Consultants interprets it as any commercial agreement under which a sponsor provides financial or other support to establish a link between the sponsor's image, brand or products and the activities of its organization in exchange for the right to advertise this link. language and or receive certain and predetermined direct or indirect benefits.Sponsorship goals can vary significantly: they include brand promotion, corporate development, image change, building new business-to-business relationships, building media resonance, expanding business, and growing sales to stand out from other advertisers. Importantly, sponsorship works as a communication in cases where advertising is prohibited or legally restricted, which prevents its effective use.

Charity - voluntary and unpaid activities of individuals or organizations to provide assistance to individuals or organizations in the form of providing property, funds, works, services and other support. Unlike the sponsor, the benefactor does not expect to benefit from his actions and does not claim it even in cases where this benefit occurs. Unlike sponsorship, charity can be hidden - secret or anonymous [8].

Patronage - material support of organizations or individual figures of culture and art, provided by private donors on their own initiative and by personal choice. The motives of charity are connected, first of all, with compassion and mercy, the motives of patronage are connected with social mutual aid and protectionism. Like, the goals of charity - to ensure social well-being in society, the goals of patronage - the preservation and development of cultural heritage.Culture, like the Philharmonic and classical music, is a platform where people meet, communicate and get new ideas, and business is basically successful communication. In Europe, concerts have already become a tool for communication in business, and sponsors (for example, 
Audi, Porsche, Rolex) understand that this is a new means of communication: when you sponsor something, it builds your image and brand.

Corporate social responsibility is part of the company's ongoing business development strategy, which is determined by the geography of corporate activities and allows through charitable actions and programs to positively influence the communities of individuals and legal entities that influence the company's business. This is a positive influence of the brand on everything that happens around its activities; the responsibility of the enterprise for the impact of its decisions and actions on society, the environment through transparent and ethical behavior; it is an investment in one's own reputation.

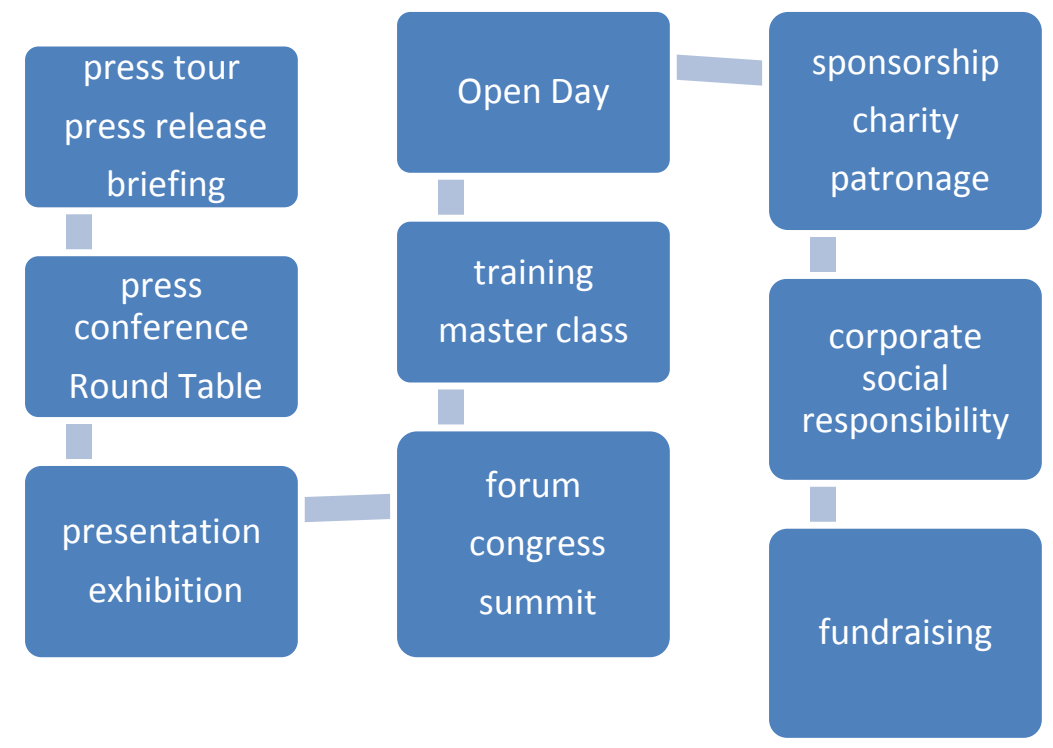

Fig. 2. Non-network PR technologies

Fundraising - organized search and collection of financial and other funds, in particular, for the implementation of charitable support of socially significant projects, programs and actions, public institutions. This is an activity to attract and accumulate funds from various sources for the implementation of socio-cultural projects and programs, which usually do not have direct commercial benefits and are short-term. The main tasks of fundraising are: attracting resources for targeted programs, socially significant and scientific projects, collecting new ideas for future programs, supporting target groups and helping individuals to realize themselves, increasing the image of the organization and strengthening public confidence in it.

Of course, this is by no means a complete list of PR technologies that are actively used in government, commercial, non-commercial, business, cultural and other environments.

\subsection{PR tools \& institutions of social memory's activity}

The basic element of today's culture is the library, which, unfortunately, has been "neglected" lately. The mission of libraries is quite simple and complex at the same time - it is the formation of thinking and creative generation. Therefore, in order to involve people in sociocultural and educational activities, libraries have to take into account the challenges of today and keep up with the times. That is why, in order to remain a popular institution, libraries are expanding their scope of activity and using modern PR technology to stay on time. Project activity is especially popular in the activities of libraries. Implementation of projects and programs involves a variety of forms of activity to achieve the declared objectives. Among the most common are trainings, round tables, quests, festivals, holidays, master classes, game programs, workshops, exhibitions, competitions, presentations, consultations, communication hours, information messages, seminars, etc $[4 ; 9 ; 12]$.

Historical memory cannot be considered complete without the maximum possible involvement in the scientific circulation of huge arrays of documents contained in the funds of 
state archives. Therefore, the main processes in archival business are the physical preservation of archival documents, accounting and providing access (direct and intellectual) to them.Thus, the meaning and purpose of the existence of archival institutions today is to provide all members of society with equal, unrestricted access to documentary retrospective information. Access to archives is a manifestation of one of the basic human rights: the right to information. One of the key areas of organizing the widest possible access to archival resources is the electronic translation of the reference apparatus of archives and archival documents - ie the formation of digital information space.In the context of the development of an open society, archives use one of the most popular PR tools - the availability of its own web resource. Modern methods of representation of archival information also include the organization of exhibitions of archival documents, which operate on the Internet in the mode of online exhibitions. Exhibitions, as an important direction of PR-technologies of the archive in the modern social and communication environment, are designed for all three types of interaction with the environment $[4 ; 11]$.

Increasing public interest in the sources of spirituality, the study of centuries-old traditions highlights the study of the preservation of historical and cultural heritage, the use of new forms of access and dissemination of national cultural heritage in the country and abroad. This fully applies to monuments stored in museums. In modern conditions, Ukrainian museums are entrusted with the mission of relaying the information potential of museum institutions to Ukrainian society, diverse communication with society and its institutions with modern tools provided by the information society. At present, all regional museums have their own websites, which serve as the main communication channel with the public. At the same time, they act as information channels and platforms on the Internet for placing the necessary information that provides citizens with access to the nation's cultural heritage. The most popular PR technologies used by social memory institutes today can be found in the table below [1].

Table 1. PR tools in libraries, museums, archives

\begin{tabular}{|c|c|c|}
\hline Libraries & Museums & Archives \\
\hline $\begin{array}{l}\text { - own website } \\
\text { - web pages in social networks } \\
\text { - trainings } \\
\text { - round tables, seminars } \\
\text { - quests, festivals, organization of } \\
\text { thematic holidays, master classes, } \\
\text { game programs (children's libraries), } \\
\text { - exhibitions, presentations of } \\
\text { publications, books, publishing } \\
\text { houses, etc. }\end{array}$ & $\begin{array}{l}\text { - own website } \\
\text { - web pages in social networks } \\
\text { - virtual exhibitions } \\
\text { - announcements and press } \\
\text { releases } \\
\text { - } 3 \mathrm{D} \text { excursions }\end{array}$ & $\begin{array}{l}\text { - own website } \\
\text { - online reception } \\
\text { - holding round tables } \\
\text { - online / offline exhibition } \\
\text { of documents } \\
\text { - printed materials } \\
\text { - web pages in social } \\
\text { networks } \\
\text { - announcements and press } \\
\text { releases }\end{array}$ \\
\hline
\end{tabular}

\section{CONCLUSIONS}

At the present stage of building a civil society, the main purpose of which is the development of social and cultural space, in which citizens focus not only on their own interests but also on interaction with each other, the activities of social memory institutions institutions) that involve society in the national cultural heritage. Since social memory is the bearer of values and norms of different social groups, able to accumulate and store the so-called "social property (capital)", the institutions of social memory ensure its use in the processes of communication and reproduction of accumulated social information. It is in this context that the social communications of social memory institutions become relevant, which, in parallel with the development of the information society, are transformed and acquire new forms. For example, there is a change in the format of children's libraries: from the library-book collection to the library-public institution, the library as a socio-cultural center of the community. In this regard, new forms of communication appear: the development of social partnership; mastering organizational and communication competencies for cooperation with the community, local and central authorities, business, mass media, public national and international organizations; 
creation of a creative educational and communicative space to reveal the inner potential of children, their integration into the community; coverage of libraries in the media, the use of PR and advertising to promote their activities. Library and archival institutions do not lag behind, which, adhering to the principle of free access to information, try to provide all members of Ukrainian society with equal, unrestricted access to documentary retrospective information and historical and cultural heritage of Ukraine. Today's communication technologies of archival institutions are represented by expanding access to archival documents, introduction of modern information technologies, including the provision of archival electronic services to users, preparation of collections of documents, monographs, biographical and reference publications, creating a system of information resources integrated into the world information space. New forms of communication are also used, among which online exhibitions are gaining popularity as a modern means of representing archival information.Museum institutions also preserve the national historical and cultural heritage with the help of modern electronic technologies. After all, the use of modern electronic communication technologies by museums (online museum tours, online exhibitions of museum collections, etc.) is a means of involving broad sections of society in national cultural treasures, the opportunity to promote Ukrainian cultural heritage in their own country and world and preserve it for future generations.

\section{REFERENCE}

[1] Божук Л., Клиніна Т. Національна історико-культурна спадщина: новітні засоби збереження та використання. Інформація, комунікація, суспільство 2019: матеріали 8-ої Міжнародної наукової конференції ІКС-2019. Львів: Видавництво Львівської політехніки, 2019. С.105-106.

[2] Дубровіна Л.А., Киридон А.М., Матяш І.Б. Інституції пам'яті: архіви, бібліотеки, музеї та культурноісторичні заповідники. Енциклопедія історії України: Україна - Украӥнці. Кн. 2 / Редкол.: В. А. Смолій (голова) та ін. НАН України. Інститут історії України. Київ: «Наукова думка», 2019. 842 с. URL: http://www.history.org.ua/?termin=2.23.

[3] Тюрменко I.I. Зв’язки з громадськістю в діяльності державних архівних установ Півдня України. Південь Украйни: етнокультурний, мовний, культурний та релігійний виміри: зб. наук. працьь. Вип. 6. Херсон: ФОП Грінь Д.С., 2017. С. 371-376. URL: http://resource.history.org.ua/cgibin/eiu/history.exe?\&I21DBN=ELIB\&P21DBN=ELIB\&S21STN= $1 \& \mathrm{~S} 21 \mathrm{REF}=10 \& \mathrm{~S} 21 \mathrm{FMT}=$ elib all $\& \mathrm{C} 21 \mathrm{COM}=\mathrm{S} \& \mathrm{~S} 21 \mathrm{CNR}=20 \& \mathrm{~S} 21 \mathrm{P} 01=0 \& \mathrm{~S} 21 \mathrm{P} 02=0 \& \mathrm{~S} 21 \mathrm{P} 03=\mathrm{ID}=\& \mathrm{~S} 21$ COLORTERMS=0\&S21STR=0013171.

[4] Тюрменко I.I., Халецька Л.П., Божук Л.В., Курченко Т.Є., Клиніна Т.С. Установи соціальної пам’яті у соціокультурному інформаційному просторі. Соціальні комунікації інформаційного суспільства: теоретичні та прикладні аспекти: монографія. Київ: Талком, 2020. С. 108-158.

[5] International Public Relations Network: IPRN. URL: http://iprn.com/

[6] Public relations network a world of exposure. URL: https://www.pr-network.biz/.

[7] PR on the Internet. URL: https://webstudio2u.net/ua/internet-ad/456-internet-pr.html.

[8] What is PR and how does it work online? URL:https://luxsite.ua/ua/chto-takoe-pr-i-kak-on-rabotaet-v-internet.

[9] Khaletska L., Klynina T. Kondrashevska Y., Peleshchyshyn A. Network communication technologies in the activity of children's libraries of Ukraine. The 2nd International Workshop on Control, Optimisation and Analytical Processing of Social Networks (COAPSN 2020), May 21, 2020. Lviv, 2020. 86-100 pp.

[10] Klynina T.S. Network PR tools. ICS-2020: Інформація, комунікація, суспільство, матеріали міжнароднопрактичної конфереренції, Львів, 21-23 травня 2020. С. 45-47.

[11] Tiurmenko I., Bozhuk L., Smolnikov Y. (eds). Digital Communications of Ukraine Archival Institutions. Control, Optimisation and Analytical Processing of Social Networks (COAPSN 2020). CEUR Workshop Proceedings. Vol. 2616 (2020), pp. 296-307. URL: http://ceur-ws.org/Vol-2616/paper25.pdf.

Tiurmenko I., Bozhuk L., Khaletska L., Struk I., Buriachok V. Communication Library Mechanisms for Children's

Social Integration. Proceedings of the International Workshop on Conflict Management in Global Information

Networks (CMiGIN), Lviv, 2019, volum 2588, pp. 533-544. URL: http://ceur-ws.org/Vol-2588/paper45.pdf 